In the article the tendency of activization of scientific interest in ethno-pedagogical and ethno-cultural problems in the field of theory and methods of musical education is considered. Ethno-pedagogical culture of a future teacher-musician is specified as an integral part of the general vocational and pedagogical culture. Its main sense constants are formulated, which include: reliance on the traditions of Ukrainian national culture represented by the Ukrainian folk music of different genres and classical musical art; the reliance on spiritual culture as a focus on the spiritual values of the Ukrainian national culture, in particular, on the values-relationships offered by the Ukrainian folk deontology and values-means, which include national symbols, folk mythology, folk calendar, folk knowledge; the reliance on the aesthetization of the socio-normative culture of the people as an orientation towards introducing artistic and aesthetic content into the material values of Ukrainian national culture, in particular, in ritual, folk architecture, costume, folk crafts.

The leading ideas of Ukrainians are defined, among them are considered: the idea of unity, the idea of Ukrainian cosmism and the idea of national self-preservation. It is noted that the support of the teacher-musician during his professional activity on the sense constants of ethno-pedagogical culture makes it possible to broadcast the centuries-old experience of folk education on the basis of creative pedagogical interpretation of the philosophy and psychology of Ukrainian society. It is proved: the importance of studying the socio-normative culture of Ukrainians from the standpoint of integrity; necessity of pedagogical stimulation of motivated students to independent in-depth study of its components; the significance of laying the foundations of any Ukrainian educational deontology on the basis of any educational process in Ukraine, which ensures the practical functioning of the humane relations between the participants of the specified process; the expediency of future educators-musicians to understand the features of the Ukrainian people, one of which is the aesthetization of folk life, poetic-lyrical attitude to the beauty of Ukrainian nature.

It is proposed to increase the planning of classroom hours for ethnographic and ethno-pedagogical training courses, as well as to introduce folklore practices in professional training of teachers-musicians.

Key words: ethnopedagogical culture, pedagogue-musician, values of Ukrainian folk pedagogy, Ukrainian folk music, Ukrainian folk deontology, sense constants, human relations. ВІДРОДЖЕННЯ

\title{
UKRAINIAN CHORAL ART IN THE FIRST THIRD OF THE XX CENTURY IN THE CONTEXT OF THE PROCESSES OF NATIONAL CULTURAL REVIVAL
}

у статті розглядаються особливості українського хорового мистецтва. Автори звертаються до маловідомої історії становлення хорового мистецтва першої третини XX cm. у контексті процесів національного культурного відродження. Розглядаються віхи просвітницької діяльності вітчизняних музикантів та зростання професіоналізму й інтересу до національних здобутків серед широких верств населення.

Ключові слова: хорове мистецтво, культурно-просвітницька діяльність, традиції, виховання.

(c) Яніна Лисенко, Дарія Коротенко, 2019 
На початку XX ст. на теренах України відбувається національно-культурне відродження, що було обумовлено декількома чинниками. Насамперед, це загальна активізація суспільного, зокрема музичного життя більшості культурних центрів на українських землях, результатом якої стало виникнення низки концертно-театральних установ, музичних товариств і навчальних закладів, що створило умови для виховання національних високопрофесійних кадрів.

Подібні передумови, а також неповторна національна пісенно-хорова спадщина, багатовікові традиції хорової творчості, виконавства та освіти, здобутки музикознавчої думки обумовили позитивну динаміку розвитку хорової культури України, а саме: хорові колективи займалися не лише концертною діяльністю, а й організацією конкурсів, фестивалів, нотодрукуванням.

Об'єктом дослідження виступили процеси українського культурно-національного відродження (середина XIX - початок XX ст.). Предмет дослідження охоплює українське хорове мистецтво першої третини XX століття. Методологія репрезентована історико-порівняльним аналізом та методами синтезу, узагальнення, структурування та спостереження. Наукова новизна статті полягає у зверненні до маловідомої історії становлення хорового мистецтва першої третини XX ст. у контексті процесів національного культурного відродження.

Мета статmі: висвітлення творчої діяльності хорових осередків західного регіону України в аспекті музичного просвітництва.

Історико-культурний доробок із вивчення хорового мистецтва $€$ предметом спеціальних наукових студій низки дослідників. Зокрема, детальний аналіз хорового мистецтва як феномену культури здійснено в працях наступних дослідників: Б. Асаф'єва [1], А. Валіахметової [4]. Особливе місце займає наукова розвідка А. Свешникова [11], який грунтовно вивчав питання хорової творчості, а також дослідження М. Кузьміна [7], Л. Кияновської [6], Т. Ханика [13], у яких аналізується хорове життя найбільших культурних центрів України. 3 нещодавніх досліджень варто виділити такі: монографії І. Гулеско [5], О. Бенч-Шокало [2], І. Бермеса [3]; дисертаційна робота Н. Синкевич [12] тощо. Також варто відзначити праці загального характеру, зокрема наукові розвідки Ю. Лаптєва [8], В. Леонтьєва [9] та В. Личкової [10].

Духовне життя української спільноти у перші десятиліття XX ст. позначене змістовною наповненістю усіх його сфер. У ньому отримали свій відбиток складні політичні, економічні та соціальні реалії того часу. В ці роки виразно простежується загальна тенденція до зростання національної самосвідомості різних прошарків суспільства. Зокрема, вагомим надбанням українського народу в царині духовності стало й хорове мистецтво. Виняткову роль в становленні української хорової школи сучасної епохи відіграла багатогранна творча праця великого сузір'я сподвижників хорового мистецтва, серед яких такі пасіонарні особистості як М. Лисенко, М. Леонтович, К. Стеценко, О. Кошиць, Я. Яциневич, Н. Городовенко та інші.

Розвиток хорової творчості на західних українських землях позначений прагненням авторів підкреслити етнічний початок у своїх музичних композиціях.

Більше підтримки мали досягнення українських композиторів, які прагнули підкреслювати етнічне у своїй мові на західних українських землях. Особливо віталося прагнення пропагувати зразки українського музичного фольклору. Особливий інтерес викликало кобзарське мистецтво та хорові обробки української народної пісні М. Лисенка, М. Леонтовича, К. Стеценка, які прагнули зробити пісню надбанням найбільш широких верств населення. Вони створювали їх як для професійних, так і самодіяльних колективів [6, с. 43].

Проте входила українська професійна творчість у мистецький та просвітницький обіг з великими, інколи непереборними труднощами. Значна підтримка надходила від музичнохорових товариств “Боян”, які діяли на Галичині й Буковині у майже всіх великих і маленьких західноукраїнських містах. Активними членами таких товариств були Є. Барвінська, А. Вахнянин, Р. Ганінчак, Ф. Колесса, С. Людкевич, С. Федак. Серед засновників і перших керівників товариств були: М. Копко (“Львівський Боян”), Й. Кишакевич (“Перемишльський Боян”), В. і О. Ніжанківські (“Стрийський Боян”) [1, с. 123]. 
Важливим видається національна спрямованість творчості українських композиторів, але репертуар хорів далеко виходив за їі межі. Перш за все, займалися аранжуванням народних слов'янських пісень (українських, російських, польських, чеських, сербських, болгарських тощо). Завдяки виступів “Боянів" українські слухачі були ознайомлені з низкою творів відомих класиків, а саме О. Бородіна, М. Глинки, С. Танєєва, П. Чайковського та інших. На концертах "Боянів" нерідко звучала музика польських, чеських та західноєвропейських композиторів.

Щодо пісенного змісту, варто зазначити певні особливості виконання програми “Боянів" із урахуванням символічності та цілеспрямованості тематичного характеру, зокрема на роковини Т. Шевченка насамперед лунали такі композиції як кантата "Радуйся, ниво неполитая" М. Лисенка, твір-кантата “Б'ють пороги”, поетика "На вічну пам'ять Котляревському” М. Лисенка, “Хор бранців” з поеми “Гамалії” М. Лисенка, кантата-симфонія “Кавказ” С. Людкевича, драма “Вечорниці” П. Ніщинського, хоровий твір “Хустина” Г. Топольницького, кантати Й. Кишакевича та інших. У виконанні цих програм брали участь також військові симфонічні або духові оркестри, що переважно складалися з чеських музикантів.

Окрему увагу слід приділити творчій, взаємоспрямованій професійній діяльності “Боянів" у Львові, Перемишлі, Станіславі, які фактично стали взірцем для хорових українських колективів - разом виступали як метри хорової справи, так і шкільні, гімназійні, студентські хори, а також хорові колективи селян. Особливість цього напряму полягала у тому, що активну участь в святкуванні річниць та інших урочистих подій брали не тільки хорові колективи, а й вокальні та інструментальні солісти як професійні митці, так і аматори.

Так, у 1898 році з нагоди 50-ліття скасування в Галичині панщини у Львові виступив хор і оркестр з села Махнова поблизу Рави Руської, а в Коломиї - хор з Печеніжина, що виконав “3 окрушків” Ф. Колесси і “Огні горять” С. Воробкевича. В 1904 році в Тернополі співали мішані хори з сіл Острова та Івачіва, грав оркестр з Давидова [13, с. 148].

Важливою подією для західноукраїнських земель став приїзд М. Лисенка з нагоди тридцятип'яти річного ювілею його творчої діяльності. Ця подія супроводжувалася пишними урочистостями: концерти відбулися 7 та 8 грудня 1903 року в залі Львівської філармонії. На них збірний хор "Боянів" (більше 300 хористів під керівництвом О. Ніжанківського виконав кантати М. Лисенка “На вічну пам'ять Котляревському” та “Радуйся, ниво неполитая”. В концертах виступив сам композитор, а також брала участь відома співачка Філомена Лопатинська. Святкування продовжилося і в Чернівцях, де “Буковинському Боянові” М. Лисенко присвятив хоровий твір під назвою сон “Сон”, написаний на слова О. Маковея.

“Бояни” займалися не лише концертною діяльністю. Так, наприклад, львівський “Боян” час від часу організовував конкурси на хорові твори і солоспіви, що сприяло збагаченню української музичної літератури.

Необхідно зауважити, що окрім культурно-просвітницької діяльності товариства займалися друкуванням нотного матеріалу. Так, Львівський “Боян” видав 32, а Станіславський 22 збірки рідкісних народних творів, переважно українських авторів.

Важливою віхою у діяльності “Боянів" була організація навчальної роботи на українських землях, а саме відкриття музичних шкіл (станіславська у 1900 р., буковинська у 1905 р., тернопільська у 1913 р. львівська у 1897 р. , а в 1903 році був заснований об'єднаний у Вищий музичний інститут “Союзі співацьких і музичних товариств". У зимовий період “Бояни”, як інші товариства, влаштовували вечорниці, бали, танцювальні й музично-декламаційні вечори тощо $[6$, с. $214 ; 13$, с. 52$]$.

У Львові, окрім “Бояна”, найбільш інтенсивну концертно-просвітницьку діяльність здійснювало товариство “академічного" (тобто студентського) хору “Бандурист”, який був заснований 1905 році на базі Львівського університету. До його складу увійшли студенти Політехніки, Академії ветеринарної медицини й Академії зовнішньої торгівлі. Мету товариства визначив один із перших параграфів статуту: "Плекання українського національного співу як хорального, так і сольного, а також інструментальної музики”. Багато років диригентами 
хору були I. Смолинський і П. Артимовський. Концертні програми “Бандуриста" близькі “Боянам", тому у великих містах, таких як Львів, обидва колективи часто виступали разом. У концертах “Бояна" і “Бандуриста” брали участь солісти - вокалісти й інструменталісти. Серед них слід відзначити виступи відомих оперних співачок і співаків (С. і А. Крушельницьких, Ф. Лопатинської, М. Сіяківни, І. Сологубівни, М. Менцинського, М. Голинського, О. Носалевича та ін.). Окрім того, “Бандурист” майже кожного року робив турне містами й селищами Галичини, Буковини, Закарпаття.

До програм концертів уходили також інструментальні номери, які виконували здебільшого піаністи (В. Барвінський, О. Бірецька, О. Бережницький, В. Божейквіна, С. Дністрянська, М. Кміцикевичівна, О. Окуневська (учениця М. Лисенка), О. і Г. Прокешівни, О. Ціпаповська, Д. та І. Шухевичі); скрипалі (Р. Криштальський, Є. Перфецький, Р. Придаткевич, О. Садовський); віолончеліст Б. Бережницький. Разом із музичними товариствами часто виступали й виконавці на народних інструментах (бандурист Г. Хоткевич), також окремі польські виконавці, як, наприклад, відомі співаки Я. Кролевич-Байдова, А. Людвіг, Ю. Шиманський, віолончеліст А. Вольфсталь, піаніст-композитор Я. Галль тощо [1, с. 121-123].

Активізація діяльності галицьких митців на початку XX ст. зумовлена кількома чинниками. В цей час спостерігається загальне пожвавлення не тільки суспільного, а й музичного життя більшості культурних центрів, насамперед, виникнення низки концертно-театральних установ, музичних товариств та навчальних закладів, зокрема консерваторії Галицького музичного товариства у Львові, що створило умови для виховання своїх національних високопрофесійних кадрів.

Вищезгадані установи власними силами організовували проведення концертів камерної, хорової і симфонічної музики, сприяли гастрольній діяльності, популяризуючи для простого українського народу творіння геніїв світової класики. Зокрема, завдяки їм за період з 1896 по 1917 рр. прозвучали окремі увертюри, всі симфонії та інструментальні концерти Л. ван Бетховена. В камерних концертах, окрім величезної кількості вокальних та сольних інструментальних творів, виконувались численні тріо, квартети, квінтети та інші камерні ансамблі для різного складу інструментів. Окрім українських музичних товариств, активну участь у просвітницькій діяльності на західноукраїнських теренах брали польські музиканти, які включали у свій репертуар багато творів своїх сучасників. Чоловічі хори “Лютня" та "Ехо” брали участь в українських урочистостях, виконуючи поряд з творами польських та інших авторів, композиції М. Лисенка, Д. Бортнянського, І. Лаврівського, П. Ніщинського, А. Вахтянина, С. Воробкевича, М. Вербицького, О. Нижанського, а також українські народні пісні [7, с. 109].

Значну культурно-просвітницьку роботу проводили також чинне з 70-х pp. XIX ст. “Літературно-художнє коло”, до складу якого входили видатні польські літератори, художники й музиканти, а також існуюче від початку 1900 р. “Музичне коло”, яке влаштовувало лекції на музичні теми, концерти-лекції, виступи кращих учнів музичних навчальних закладів та ix педагогів.

Спорідненість прагнень представників української та польської інтелігенції, їх боротьба за право на існування своєї культури, об'єднували їх зусилля. I не тільки у виконавській практиці постійно зростаючий попит на музичну літературу як наслідок цієї практики обумовив зростання ролі видавничої діяльності. Цілеспрямовану проукраїнську політику веде видавництво “Торбан”, засноване у 1906 р. Упродовж 34 років ним було надруковано велику кількість музичних творів у різних жанрах: хорових, камерно-інструментальних, солоспівів, обробок українських народних пісень, що сприяло популяризації української музики. В цьому ж напрямі працюють і перші фабрики грамзапису. За даними I. Бермеса: "На дисках записували українські народні пісні, деякі твори М. Лисенка (уривки з “Наталки Полтавки”, “Чорноморців", солоспіви), окремі епізоди з “Запорожця за Дунаєм" С. Гулака-Артемовського та ін. У 1914 році з'являється нова партія грамплатівок із записами українських народних пісень, арій і мелодій з українських опер, оперет, музичних вистав (зокрема з “Катерини”, “Еней на 
мандрівці", “Нещасне кохання”, “Перехитрили”, “Не ходи, Грицю”, “Підгіряни”, “Безталанна” та ін." [3, с. 134].

Отже, на західноукраїнських землях так само, як і на східних, завдяки просвітницькій діяльності вітчизняних музикантів, спостерігається зростання професіоналізму та інтересу до національних здобутків серед широких верств населення. Незважаючи на різницю у формах і засобах цієї діяльності, їх об'єднує спрямованість на відродження та збереження національних традицій, зростання ролі здобутків вітчизняної культури у вихованні національної самосвідомості українства.

Українське хорове мистецтво першої третини XX ст. $є$ вагомим надбанням для української культури. Неповторна національна пісенно-хорова спадщина, багатовікові традиції хорової творчості, виконавства та освіти, а також здобутки музикознавчої думки, обумовили позитивну динаміку розвитку хорової культури як на початку XX ст., так і в наступні роки.

Особливо віталось прагнення пропагувати зразки українського музичного фольклору. Хорові колективи займалися не лише концертною діяльністю, але й організацією конкурсів хорових творів та солоспівів, що сприяло збагаченню української музичної культури. Культурно-просвітницька діяльність охоплювала організацію вечорниць, балів, танцювальні й музично-декламаційні вечори, а також нотодрукування різноманітних творів, переважно українських авторів.

У цей час спостерігається загальне пожвавлення не тільки суспільного, а й музичного життя більшості культурних центрів, що зумовило виникнення низки концертно-театральних установ, музичних товариств, навчальних закладів, зокрема консерваторій, що створило умови для виховання своїх національних високопрофесійних кадрів.

Здобутки концертно-просвітницької діяльності хорових колективів у першій третині XX cт. та їх вплив на подальший розвиток, відродження та збереження національних традицій потребують подальшого глибокого науково-дослідного пошуку.

\section{Список використаних джерел}

1. Асафьев Б. Хор как воспитатель слушателя // О хоровом искусстве. М. : Музыка, 1980. 216 c.

2. Бенч-Шокало О.Г. Український хоровий спів: актуалізація звичаєвої традиції. Київ : Український світ, 2002. 440 с.

3. Бермес І.Л. Український хоровий спів як соціокультурне явище. Дрогобич : Посвіт, 2013. 432 c.

4. Валиахметова А.Н. Хоровое искусство как форма духовной культуры // Педагогика художественного образования: история, методология, практика. Ч. 1. Казань : ТГГПУ, 2011. 519 c.

5. Гулеско I.І. Національний хоровий стиль. Харків : ХДІК, 1994. 108 с.

6. Кияновська Л.О. Стильова еволюція галицької музичної культури XIX-XX ст. Тернопіль: Астон, 2000. 339 с.

7. Кузьмін М. Забуті сторінки музичного життя Києва. Київ : Музична Україна, 1972. $228 \mathrm{c}$.

8. Лаптєв Ю.К. Общество, продуцирующее культуру // Вестник Московского государственного университета культуры и искусств. № 3. 2007. С. 17-20.

9. Леонтьєва В.Н. Культуротворческий процес: основание и начало. Харков : Консум, 2003. 216 c.

10. Личкова В. Дивосад культури: вибрані статті з естетики, культурології, філософії мистецтва. Чернігів : Деснянська правда, 2006. 160 с.

11. Свешников А.В. Хоровое пение искусство истинно народное. М. : Просвещение, 1962. C. 9-14. 
12. Синкевич Н.Т. Соціокультурні функції українського хорового мистецтва : автореф. дис. ... канд. мистецтвознав.: 26.00.01 Теорія та історія культури. Київ, 2012. 20 с.

13. Ханик Л.Р. Історія хорового товариства “Боян”. Львів, 1999. 123 с.

The article deals with the peculiarities of Ukrainian choral art. The main idea of the paper is to examine the little-known history of the development of choral art in the first third of the twentieth century in the context of the processes of national cultural revival.

The article gives a detailed analysis of the milestones of the enlightening activity of native musicians and the growth of professionalism and interest in national achievements among the general population. Further, the authors consider the positive influence of the development of Ukrainian choral art on cultural revival on the Ukrainian lands.

Special attention is given to the issue of the activities of circles and music societies: "Boyan", "Bandurist", "Lute", "Echo", "Literary and Art Circle", "Musical Circle" and others.

The article shows that many well-known contemporary cultural figures were among solo performers, for example, the performances of famous opera singers: S. and A. Krushelnytski, F. Lopatinska, M. Siyakivna (soloists of the opera in Barcelona), I. Sologubivna (prima donnas of the opera in Genoa), M. Mentsinskyi, M. Holynskyi, A. Nosalevych and others. The concert program also included instrumental pieces by pianists D. and I. Shukhevychi, O. Okunevska (student by N. Lysenko), O. and G. Prokeshivny, O. Tsipapovska, M. Kmitsykevicivna, V. Bozheikvina, O. Biretska, S. Dnistryanska, V. Barvinskyi, violinists O. Berezhnitskyi, E. Perfetskyi, R. Pridatkevych, O. Sadovskyi, R. Krishtalskyi, cellist B. Berezhnitskyi. An exceptional role in the formation of the Ukrainian choral school was played by the creative work of such passionary personalities as M. Lysenko, M. Leontovych, K. Stetsenko, O. Koshytsia, J. Yatsinevych, $N$. Horodovenko and others.

The authors come to the conclusion that such associations engaged not only in concert activity, but also popularized the work of Ukrainian composers, published notes, organized contests, parties. This activity positively influenced the preservation of the achievements of the Ukrainian ethnic and national cultural heritage.

Key words: choral art, cultural and educational activity, traditions, education.

\section{РОЗВИТОК ТВОРЧИХ ЗДІБНОСТЕЙ УЧНІВСЬКОЇ МОЛОДІ НА ОСНОВІ МУЗИЧНОГО СПРИЙМАННЯ ЯК ОДНА 3 ПЕРВИННИХ ПРОБЛЕМ СУЧАСНОЇ МУЗИЧНОЇ ПЕДАГОГІКИ}

\section{THE DEVELOPMENT OF PUPILS' MUSICAL CREATIVE ABILITIES ON THE BASIS OF MUSICAL PERCEPTION AS ONE OF THE PRIMARY PROBLEMS OF MODERN MUSICAL PEDAGOGY}

Стаття спрямована на обьрунтування теорії дослідження проблеми розвитку творчих здібностей, на загальну інтегративну спрямованість освіти, на необхідність посилення взаємодії мистецтва, на формування поліхудожніх комплексів, що грунтується на розвитку здібностей школярів та передбачає підвищення їхньої естетичної культури й гармонійного виховання кожного члена суспільства засобами музичного мистеитва.

Ключові слова: здібності, музичні здібності, музичне сприймання, музична педагогіка, музичне мистеитво.

(c) Микола Ляшко, 2019 